\title{
Benzimidazolium Salts Bearing 2-methyl-1,4- benzodioxane Group: Synthesis, Characterization, Computational Studies, In vitro Antioxidant and Antimicrobial Activity
}

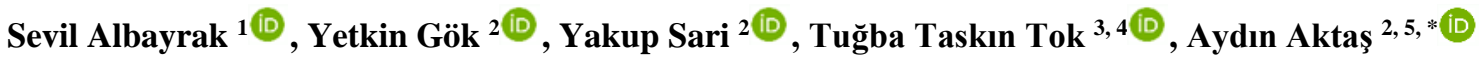 \\ 1 Erciyes University, Faculty of Sciences, Department of Biology, 38039, Kayseri, Turkey; salbayrak@ erciyes.edu.tr (S.A.); \\ 2 Inönü University, Faculty of Arts and Sciences, Department of Chemistry, 44280, Malatya, Turkey; \\ yetkin.gok@inonu.edu.tr (Y.G.),yaakupst@hotmail.com (Y.S.); \\ 3 Faculty of Arts and Sciences, Department of Chemistry, Gaziantep University, 27310, Gaziantep, Turkey; \\ ttaskin@gantep.edu.tr (T.T.T.); \\ 4 Institute of Health Sciences, Department of Bioinformatics and Computational Biology, Gaziantep University, 27310, \\ Gaziantep, Turkey; ttaskin@gantep.edu.tr (T.T.T.); \\ 5 Inonu University, Vocational School of Health Service, 44280, Malatya, Turkey; aydin_aktas@inonu.edu.tr (A.A.); \\ * Correspondence: aydin_aktas@inonu.edu.tr;
}

Received: 28.12.2020; Revised: 28.01.2021; Accepted: 2.02.2021; Published: 9.02.2021

\begin{abstract}
This study contains the synthesis of the 1-(2-methyl-1,4-benzodioxane)benzimidazole and 2-methyl-1,4-benzodioxane substituted benzimidazolium salts. The benzimidazolium salts were synthesized from the reaction of the 1-(2-methyl-1,4-benzodioxane)benzimidazole and various aryl chlorides. All compounds were characterized using ${ }^{1} \mathrm{H}$ NMR, ${ }^{13} \mathrm{C}$ NMR, FTIR spectroscopy, and elemental analysis techniques. The antioxidant properties of benzimidazolium salts were examined by 2,2-diphenyl-1-picrylhydrazyl (DPPH) free radical scavenging and hydrogen peroxide scavenging ability assays. The compounds showed a moderate inhibitory effect on DPPH radical (The percent inhibition $=29.53-39.75$ ). Also, the compounds exhibited significant $\mathrm{H}_{2} \mathrm{O}_{2}$ radical scavenging activity. Antimicrobial activities of the compounds were examined against nine bacterial strains and Candida albicans. All compounds displayed marked antimicrobial activity against tested microorganisms, particularly against Pseudomonas aeruginosa, Listeria monocytogenes, and C. albicans. From the computational perspective, benzimidazolium salts were also optimized at B3LYP / DMol3// DFT level using the Discovery Studio 2020 program. HOMO-LUMO analysis and molecular electrostatic potential surface (MESP) were exerted to examine the effects of benzimidazolium salts' electronic and structural properties.
\end{abstract}

Keywords: antimicrobial activity; antioxidant; benzimidazolium salts; DPPH; hydrogen peroxide; computational study.

(C) 2021 by the authors. This article is an open-access article distributed under the terms and conditions of the Creative Commons Attribution (CC BY) license (https://creativecommons.org/licenses/by/4.0/).

\section{Introduction}

The $N$-heterocyclic carbene (NHC) precursors constitute an important class of ligands for organic and organometallic chemistry [1]. In particular, the unique electronic and structural properties of NHCs enhance their reputation [2,3]. NHC ligands can be formed of 4-membered [4], 5-membered [5-7], 6-membered [8], and 7-membered [9]. However, the most used are NHCs containing 5-membered such as imidazole [5], imidazoline [6], and benzimidazole [7]. 
The benzimidazole is a bicyclic heteroaromatic molecule that is a structural isostere of naturally occurring nucleotides. Therefore, it has been extensively utilized as a useful scaffold in medicinal chemistry [10]. Recently, the biological activities of different benzimidazole derivatives have been investigated [11,12]. The benzimidazolium salts are the important benzimidazole derivatives. The benzimidazolium salts have been found to display many biological activities such as antimicrobial [13], antibiofilm [14], antifungal [15], antiviral [16], antioxidant [17], anti-inflammatory [18], anticancer [19,20] and cytotoxicity [21]. In addition to these studies, benzimidazolium salts' enzyme inhibition effects have recently been remarkable [22-27].

The development of bacterial resistance against macrolides, $\beta$-lactam antibiotics, vancomycin, and quinolones causes widespread health problems [28, 29]. There is a need to discover new antibacterial drugs with a different structure to combat these problems than the existing antibiotics [28]. Thus, the research of new antibacterial substances with new mechanisms of action is to be always important [29]. There has been much recent interest in the therapeutic potential of benzimidazole as antibacterial agents. Therefore, this situation has led us to screen the antimicrobial effects of 1-(2-methyl-1,4-benzodioxane)benzimidazole and their benzimidazolium salts.

The term structure-activity relationship (SAR) provides an understanding of the relationship between a chemical molecule structure and its biological activity. When the SAR of the compounds is examined, we believe that the electronic and structural properties of the 2-methyl-1,4-benzodioxane substituent on benzimidazole salts are important. In particular, it could be said that the benzodioxane group exhibits antioxidant and antimicrobial activity due to both weak interactions and chemical interactions. One of the most important reasons for using this group is the presence of hydrophilic dioxane moiety and hydrophobic benzene rings on the same structure. Also, the second groups (different aryl groups) on the benzimidazole are important in terms of SAR. Aryl groups perform both hydrophobic interactions and providing an electronic contribution to the molecules.

Recently, new studies on the biological activities of $N$-heterocyclic compounds such as thiadiazole, triazole, imidazolium, and benzimidazolium have been published [30-32]. We have previously carried out studies on the biological activities of benzimidazolium salts $[33,34]$ and their $\mathrm{Ag}(\mathrm{I}) \mathrm{NHC}$ complexes [27,33,35-38] and Pd(II)NHC complexes [39-43]. Here, we have described the synthesis and characterization of new 2-methyl-1,4-benzodioxanesubstituted benzimidazolium salts. The antioxidant and antimicrobial activities of all compounds have been investigated using antioxidant assays and the agar-well diffusion method. In the meantime, computational studies were carried out to illuminate their activities at the atomic level.

\section{Materials and Methods}

All synthesis, including benzimidazolium salts bearing 2-methyl-1,4-benzodioxane group 2a-f were prepared in the air atmosphere using standard Schlenk techniques. The solvents and all other reagents were commercially available from Merck, Sigma-Aldrich, and Scharlau chemical company and used without further purification. Melting points were identified in glass capillaries under air with an Electrothermal-9200 melting point apparatus. FT-IR spectra were saved in the range $400-4000 \mathrm{~cm}^{-1}$ on Perkin Elmer Spectrum 100 FT-IR spectrometer. Proton $\left({ }^{1} \mathrm{H}\right)$ and Carbon $\left({ }^{13} \mathrm{C}\right)$ NMR spectra were recorded using either a Bruker AC300P FT spectrometer operating at $300.13 \mathrm{MHz}\left({ }^{1} \mathrm{H}\right)$ and $75.47 \mathrm{MHz}\left({ }^{13} \mathrm{C}\right)$ in DMSO-d6 
with tetramethylsilane as an internal reference. Elemental analyses were performed by Inonu University Scientific and Technological Research Center (Malatya, TURKEY).

\subsection{Synthesis.}

\subsubsection{Synthesis of 1-(2-methyl-1,4-benzodioxan)benzimidazole, 1.}

For the synthesis of 1-(2-methyl-1,4-benzodioxan)benzimidazole has used the method described in the literature [23]. For this, the benzimidazole (2.36 g. $20 \mathrm{mmol})$ and $\mathrm{KOH}(1.23$ g. $22 \mathrm{mmol})$ was added in ethanol $(25 \mathrm{~mL})$ and stirred at room temperature for 1 hour. Then was added 2-bromomethyl-1,4-benzodioxane (4.58 g. $20 \mathrm{mmol}$ ). The reaction mixture was stirred for $12 \mathrm{~h}$. at $80^{\circ} \mathrm{C}$ temperatures. The solvents were evaporated under vacuum to afford the product as a viscous liquid. The crude product was crystallized from ethyl alcohol/diethyl ether mixture. Yield: $80 \%$ (4.26 g); m.p.: $100-101{ }^{\circ} \mathrm{C} ; v_{(\mathrm{CN})}: 1501 \mathrm{~cm}^{-1} .{ }^{1} \mathrm{H}$ NMR $(300 \mathrm{MHz}$, DMSO-d6) $\delta ; 3.96$ (dd, 2H, J: $9.6 \mathrm{~Hz}-\mathrm{NCH}_{2} \mathrm{CHCH}_{2} \mathrm{O}_{2} \mathrm{C}_{6} \mathrm{H}_{4}$ ); 4.54 (dd, 2H, J: $9.6 \mathrm{~Hz}$, $\left.\mathrm{NCH}_{2} \mathrm{CHCH}_{2} \mathrm{O}_{2} \mathrm{C}_{6} \mathrm{H}_{4}\right) ; 4.57\left(\mathrm{~m}, 1 \mathrm{H},-\mathrm{NCH}_{2} \mathrm{CHCH}_{2} \mathrm{O}_{2} \mathrm{C}_{6} \mathrm{H}_{4}\right) ; 6.81-8.22(\mathrm{~m}, 8 \mathrm{H}, \mathrm{Ar}-H) ; 12.45$ $(\mathrm{s}, 1 \mathrm{H},-\mathrm{NCHN}-) .{ }^{13} \mathrm{C} \mathrm{NMR}(100 \mathrm{MHz}, \mathrm{DMSO}-\mathrm{d} 6), \delta 47.1\left(-\mathrm{CH}_{2} \mathrm{CH}(\mathrm{O}) \mathrm{CH}_{2} \mathrm{O}-\right) ; 64.2(-$ $\left.\mathrm{CH}_{2} \mathrm{CH}(\mathrm{O}) \mathrm{CH}_{2} \mathrm{O}-\right) ; 72.5$ (- $\left.\mathrm{CH}_{2} \mathrm{CH}(\mathrm{O}) \mathrm{CH}_{2} \mathrm{O}-\right)$; 111.1-117.3-120.4-120.6-122.0-122.2-134.4 and 143.6-144.4 (Ar-C).

2.1.2. Synthesis of 1-(2-methyl-1,4-benzodioxane)-3-(2-methybenzyl)benzimidazolium chloride, $2 \mathrm{a}$.

For the synthesis of 2a, 1-(2-methyl-1,4-benzodioxane)benzimidazole (1,33 g, $5 \mathrm{mmol})$ and 2-methylbenzyl chloride (0.70 g, $5 \mathrm{mmol}$ ) was added in DMF (4 mL). Yield: 83\% (1.69 g), m.p.: 147-148 ${ }^{\circ} \mathrm{C} ; v_{(\mathrm{CN})}: 1560 \mathrm{~cm}^{-1} .{ }^{1} \mathrm{H}$ NMR (300 MHz, DMSO-d6), $\delta$; 2.34 (s, 3H, $\left.\mathrm{CH}_{2} \mathrm{C}_{6} \mathrm{H}_{4}\left(\mathrm{CH}_{3}\right)\right) ; 4.33$ and $4.54\left(\mathrm{dd}, 2 \mathrm{H},-\mathrm{CH}_{2} \mathrm{CH}(\mathrm{O}) \mathrm{CH}_{2} \mathrm{O}-, J: 9.3 \mathrm{~Hz}\right) ; 4.93(\mathrm{~m}, 1 \mathrm{H}$, $\left.\mathrm{CH}_{2} \mathrm{CH}(\mathrm{O}) \mathrm{CH}_{2} \mathrm{O}-\right)$; 4.92 and 5.40 (dd, 2H, $\left.-\mathrm{CH}_{2} \mathrm{CH}(\mathrm{O}) \mathrm{CH}_{2} \mathrm{O}-, \mathrm{J}: 9.6 \mathrm{~Hz}\right) ; 5.82(\mathrm{~s}, 2 \mathrm{H}$, $\left.\mathrm{CH}_{2} \mathrm{C}_{6} \mathrm{H}_{5}\right) ; 6.69-7.70$ (m, 12H, Ar- $H$ ); 11.48 (s, 1H, 2-CH). ${ }^{13} \mathrm{C}$ NMR (300 MHz, DMSO-d 6 ), $\delta ; 21.7 \quad\left(-\mathrm{CH}_{2} \mathrm{C}_{6} \mathrm{H}_{4}\left(\mathrm{CH}_{3}\right)\right) ; 47.7 \quad\left(-\mathrm{CH}_{2} \mathrm{CH}(\mathrm{O}) \mathrm{CH}_{2} \mathrm{O}-\right) ; 51.8 \quad\left(-\mathrm{CH}_{2} \mathrm{C}_{6} \mathrm{H}_{4}\left(\mathrm{CH}_{3}\right)\right) ; 64.8$ $\left.\mathrm{CH}_{2} \mathrm{CH}(\mathrm{O}) \mathrm{CH}_{2} \mathrm{O}-\right) ; 72.2\left(-\mathrm{CH}_{2} \mathrm{CH}(\mathrm{O}) \mathrm{CH}_{2} \mathrm{O}-\right) ; 113.4,113.8,114.1,117.4,117.7,122.1,127.2$, 127.8, 128.3, 129.3, 129.4, 129.5, 130.7, 132.3, 132.5, 141.4, 142.4 and 142.8 (Ar-C); 143.4 (2-CH). Anal. Calc. for $\mathrm{C}_{24} \mathrm{H}_{23} \mathrm{ClN}_{2} \mathrm{O}_{2}$ : C: 71.84, H: 5.70, N: 6.88. Found C: 71.79, H: 5.72, $\mathrm{N}: 6.86$.

2.1.3. Synthesis of 1-(2-methyl-1,4-benzodioxane)-3-(3-methylbenzyl)benzimidazolium chloride, $2 \mathrm{~b}$.

The synthesis of $\mathbf{2} \mathbf{b}$ was performed in the same method as that described for $\mathbf{2 a}$, but 3 methylbenzyl chloride $(0.70 \mathrm{~g}, 5 \mathrm{mmol})$ was used instead of 2-methylbenzyl chloride. Yield: $72 \%$ (147 g); m.p.: 140-141 ${ }^{\circ} \mathrm{C}$; $v_{(\mathrm{CN})}: 1558 \mathrm{~cm}^{-1} .{ }^{1} \mathrm{H}$ NMR (300 MHz, DMSO-d6), $\delta ; 2.33$ (s, $3 \mathrm{H},-\mathrm{CH}_{2} \mathrm{C}_{6} \mathrm{H}_{4}\left(\mathrm{CH}_{3}\right)$ ); 4.34 and 4.54 (dd, $2 \mathrm{H},-\mathrm{CH}_{2} \mathrm{CH}(\mathrm{O}) \mathrm{CH}_{2} \mathrm{O}-$, J: $\left.9.3 \mathrm{~Hz}\right) ; 5.00$ (m, 1H, $\left.\mathrm{CH}_{2} \mathrm{CH}(\mathrm{O}) \mathrm{CH}_{2} \mathrm{O}-\right)$; 4.95 and 5.60 (dd, 2H, $-\mathrm{CH}_{2} \mathrm{CH}(\mathrm{O}) \mathrm{CH}_{2} \mathrm{O}-$, J:9.6 Hz); 5.76 (s, 2H, $\mathrm{CH}_{2} \mathrm{C}_{6} \mathrm{H}_{4}\left(\mathrm{CH}_{3}\right)$ ); 6.83-7.70 (m, 12H, Ar- $H$ ); 11.40 (s, $\left.1 \mathrm{H}, 2-\mathrm{CH}\right) .{ }^{13} \mathrm{C}$ NMR (75 MHz, DMSO$\left.\mathrm{d}_{6}\right), \delta ; 21.4\left(-\mathrm{CH}_{2} \mathrm{C}_{6} \mathrm{H}_{4}\left(\mathrm{CH}_{3}\right)\right) ; 47.7\left(-\mathrm{CH}_{2} \mathrm{CH}(\mathrm{O}) \mathrm{CH}_{2} \mathrm{O}-\right) ; 51.8\left(-\mathrm{CH}_{2} \mathrm{C}_{6} \mathrm{H}_{4}\left(\mathrm{CH}_{3}\right)\right) ; 64.8$ ($\left.\mathrm{CH}_{2} \mathrm{CH}(\mathrm{O}) \mathrm{CH}_{2} \mathrm{O}-\right) ; 72.2\left(-\mathrm{CH}_{2} \mathrm{CH}(\mathrm{O}) \mathrm{CH}_{2} \mathrm{O}-\right) ; 113.4,114.1,117.4,122.1,125.2,126.6,127.2$, $128.7,128.9,129.3,130.1,130.8,131.8,132.1,132.5,139.5$ and $141.4(\mathrm{Ar}-\mathrm{C}) ; 142.9(2-\mathrm{CH})$. Anal. Calc. for $\mathrm{C}_{24} \mathrm{H}_{23} \mathrm{ClN}_{2} \mathrm{O}_{2}: \mathrm{C}: 71.84, \mathrm{H}: 5.70, \mathrm{~N}: 6.88$. Found $\mathrm{C}: 71.78, \mathrm{H}: 5.72, \mathrm{~N}: 6.85$. 
2.1.4. Synthesis of 1-(2-methyl-1,4-benzodioxane)-3-(4-methylbenzyl)benzimidazolium chloride, $2 \mathrm{c}$.

The synthesis of $\mathbf{2} \mathbf{c}$ was performed in the same method as that described for $\mathbf{2 a}$, but 4methylbenzyl chloride $(0.70 \mathrm{~g}, 5 \mathrm{mmol})$ was used instead of 2-methylbenzyl chloride. Yield:

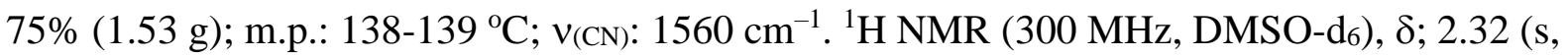
$3 \mathrm{H},-\mathrm{CH}_{2} \mathrm{C}_{6} \mathrm{H}_{4}\left(\mathrm{CH}_{3}\right)$ ); 4.35 and 4.54 (dd, $2 \mathrm{H},-\mathrm{CH}_{2} \mathrm{CH}(\mathrm{O}) \mathrm{CH}_{2} \mathrm{O}-$, J: $\left.9.3 \mathrm{~Hz}\right)$; 4.97 (m, 1H, $\mathrm{CH}_{2} \mathrm{CH}(\mathrm{O}) \mathrm{CH}_{2} \mathrm{O}-$ ); 4.92 and 5.47 (dd, 2H, - $\mathrm{CH}_{2} \mathrm{CH}(\mathrm{O}) \mathrm{CH}_{2} \mathrm{O}-$, J:9.6 Hz); 5.70 (s, 2H, $\left.\mathrm{CH}_{2} \mathrm{C}_{6} \mathrm{H}_{4}\left(\mathrm{CH}_{3}\right)\right)$; 6.68-8.95 (m, 12H, Ar- $\left.H\right)$; 11.46 (s, 1H, 2-CH). ${ }^{13} \mathrm{C}$ NMR (75 MHz, DMSOd6), $\delta ; 21.2\left(-\mathrm{CH}_{2} \mathrm{C}_{6} \mathrm{H}_{4}\left(\mathrm{CH}_{3}\right)\right) ; 47.7\left(-\mathrm{CH}_{2} \mathrm{CH}(\mathrm{O}) \mathrm{CH}_{2} \mathrm{O}-\right) ; 51.7 \quad\left(-\mathrm{CH}_{2} \mathrm{C}_{6} \mathrm{H}_{4}\left(\mathrm{CH}_{3}\right)\right) ; 64.8$ ($\left.\mathrm{CH}_{2} \mathrm{CH}(\mathrm{O}) \mathrm{CH}_{2} \mathrm{O}-\right) ; 72.2\left(-\mathrm{CH}_{2} \mathrm{CH}(\mathrm{O}) \mathrm{CH}_{2} \mathrm{O}-\right) ; 111.2,113.4,114.0,117.4,118.4,121.7,122.1$, 124.6, 127.2, 128.3, 129.1, 130.2, 131.0, 132.5, 138.7, 139.6, 141.4 and 142.9 (Ar-C); 143.2 (2-CH). Anal. Calc. for $\mathrm{C}_{24} \mathrm{H}_{23} \mathrm{ClN}_{2} \mathrm{O}_{2}: \mathrm{C}: 71.84, \mathrm{H}: 5.70, \mathrm{~N}: 6.88$. Found C: 71.87, H: 5.68, $\mathrm{N}: 6.86$.

2.1.5. Synthesis of 1-(2-methyl-1,4-benzodioxane)-3-(2,4,6-trimethylbenzyl)benzimidazolium chloride, $2 \mathrm{~d}$.

The synthesis of $\mathbf{2 d}$ was performed in the same method as that described for $\mathbf{2 a}$, but 2,4,6-trimethylbenzyl chloride ( $0.85 \mathrm{~g}, 5 \mathrm{mmol}$ ) was used instead of 2-methylbenzyl chloride. Yield: 70\% (1.52 g); m.p: 203-204 ${ }^{\circ} \mathrm{C} ; v_{(\mathrm{CN})}: 1567 \mathrm{~cm}^{-1} .{ }^{1} \mathrm{H}$ NMR (300 MHz, DMSO-d $)$, $\delta$; 2.27 and 2.31 (s, $\left.9 \mathrm{H},-\mathrm{CH}_{2} \mathrm{C}_{6} \mathrm{H}_{2}\left(\mathrm{CH}_{3}\right)_{3}\right)$; 4.07 and 4.45 (dd, $2 \mathrm{H},-\mathrm{CH}_{2} \mathrm{CH}(\mathrm{O}) \mathrm{CH}_{2} \mathrm{O}-$, J: $9.6 \mathrm{~Hz}$ ); $4.75\left(\mathrm{~m}, 1 \mathrm{H},-\mathrm{CH}_{2} \mathrm{CH}(\mathrm{O}) \mathrm{CH}_{2} \mathrm{O}-\right)$; 4.78 and 4.99 (dd, $2 \mathrm{H},-\mathrm{CH}_{2} \mathrm{CH}(\mathrm{O}) \mathrm{CH}_{2} \mathrm{O}-$, J:9.6 Hz); 5.70 (s, $\left.2 \mathrm{H},-\mathrm{CH}_{2} \mathrm{C}_{6} \mathrm{H}_{2}\left(\mathrm{CH}_{3}\right)_{3}\right) ; 6.58-8.21(\mathrm{~m}, 10 \mathrm{H}, \mathrm{Ar}-\mathrm{H}) ; 9.62$ (s, $\left.1 \mathrm{H}, 2-\mathrm{CH}\right) .{ }^{13} \mathrm{C}$ NMR $(75 \mathrm{MHz}$, DMSO-d 6$), \quad \delta ; 19.8$ and $21.2 \quad\left(-\mathrm{CH}_{2} \mathrm{C}_{6} \mathrm{H}_{4}\left(\mathrm{CH}_{3}\right)_{3}\right) ; 45.6 \quad\left(-\mathrm{CH}_{2} \mathrm{CH}(\mathrm{O}) \mathrm{CH}_{2} \mathrm{O}-\right) ; 47.0$ $\left.\mathrm{CH}_{2} \mathrm{C}_{6} \mathrm{H}_{2}\left(\mathrm{CH}_{3}\right)_{3}\right) ; 64.8\left(-\mathrm{CH}_{2} \mathrm{CH}(\mathrm{O}) \mathrm{CH}_{2} \mathrm{O}-\right) ; 71.0\left(-\mathrm{CH}_{2} \mathrm{CH}(\mathrm{O}) \mathrm{CH}_{2} \mathrm{O}-\right) ; 114.3,114.7,114.9$, 117.4, 117.7, 122.3, 126.1, 126.5, 127.4, 130.0, 131.0, 131.9, 132.2, 138.6, 139.1, 139.3, 141.2 and 142.1 (Ar-C); 143.2 (2-CH). Anal. Calc. for $\mathrm{C}_{26} \mathrm{H}_{27} \mathrm{ClN}_{2} \mathrm{O}_{2}$ : C: 71.80, H: 6.26, N: 6.44. Found C: 71.84, H: 6.24, N: 6.47.

2.1.6. Synthesis of 1-(2-methyl-1,4-benzodioxane)-3-(2,3,5,6-tetramethylbenzyl) benzimidazolium chloride, $2 \mathrm{e}$.

The synthesis of $\mathbf{2 e}$ was performed in the same method as that described for $\mathbf{2 a}$, but 2,3,5,6-tetramethylbenzyl chloride $(0.92 \mathrm{~g}, 5 \mathrm{mmol})$ was used instead of 2-methylbenzyl chloride. Yield: $70 \%$ (1.57 g); m.p.: 222-223 ${ }^{\circ} \mathrm{C}$; $v_{(\mathrm{CN})}: 1561 \mathrm{~cm}^{-1} .{ }^{1} \mathrm{H}$ NMR (300 MHz, DMSOd6), $\delta ; 2.25$ and 2.30 (s, $\left.12 \mathrm{H},-\mathrm{CH}_{2} \mathrm{C}_{6} \mathrm{H}\left(\mathrm{CH}_{3}\right) 4\right) ; 4.31$ and 4.52 (dd, $2 \mathrm{H},-\mathrm{CH}_{2} \mathrm{CH}(\mathrm{O}) \mathrm{CH}_{2} \mathrm{O}-, J$ : $9.3 \mathrm{~Hz}) ; 4.85\left(\mathrm{~m}, 1 \mathrm{H},-\mathrm{CH}_{2} \mathrm{CH}(\mathrm{O}) \mathrm{CH}_{2} \mathrm{O}-\right) ; 5.61$ and $5.72\left(\mathrm{dd}, 2 \mathrm{H},-\mathrm{CH}_{2} \mathrm{CH}(\mathrm{O}) \mathrm{CH}_{2} \mathrm{O}-, \mathrm{J}: 9.3\right.$ $\mathrm{Hz}$ ); 5.89 (s, 2H, $\left.-\mathrm{CH}_{2} \mathrm{C}_{6} \mathrm{H}\left(\mathrm{CH}_{3}\right)_{4}\right)$; 6.52-7.97 (m, 9H, Ar- $H$ ); 10.06 (s, 1H, 2-CH). ${ }^{13} \mathrm{C}$ NMR (75 MHz, DMSO-d6), $\delta$; 16.1 and $20.6\left(-\mathrm{CH}_{2} \mathrm{C}_{6} \mathrm{H}\left(\mathrm{CH}_{3}\right) 4\right) ; 47.7\left(-\mathrm{CH}_{2} \mathrm{CH}(\mathrm{O}) \mathrm{CH}_{2} \mathrm{O}-\right)$; 48.0 ($\left.\mathrm{CH}_{2} \mathrm{C}_{6} \mathrm{H}\left(\mathrm{CH}_{3}\right)_{4}\right) ; 65.7\left(-\mathrm{CH}_{2} \mathrm{CH}(\mathrm{O}) \mathrm{CH}_{2} \mathrm{O}-\right) ; 71.9\left(-\mathrm{CH}_{2} \mathrm{CH}(\mathrm{O}) \mathrm{CH}_{2} \mathrm{O}-\right) ; 112.9,113.8,114.6$, 117.1, 117.7, 121.9, 122.1, 126.9, 127.2, 127.8, 131.0, 131.8, 132.5, 133.5, 133.9, 135.1, 141.2 and 142.0 (Ar-C); 143.0 (2-CH). Anal. Calc. for $\mathrm{C}_{27} \mathrm{H}_{29} \mathrm{ClN}_{2} \mathrm{O}_{2}$ : C: 72.23, H: 6.51, N: 6.24. Found C: $72.28, \mathrm{H}: 6.47, \mathrm{~N}: 6.26$.

2.1.7. Synthesis of 1-(2-methyl-1,4-benzodioxane)-3-(naphthalenomethyl)benzimidazolium chloride, $2 \mathrm{f}$. 
The synthesis of $\mathbf{2} \mathbf{f}$ was performed in the same method as that described for $\mathbf{2 a}$, but naphthalenomethyl chloride $(0.89 \mathrm{~g}, 5 \mathrm{mmol})$ was used instead of 2-methylbenzyl chloride. Yield: 68\% (1.51 g); mp.: 239-240 ${ }^{\circ} \mathrm{C}$; $v_{(\mathrm{CN})}: 1563 \mathrm{~cm}^{-1} .{ }^{1} \mathrm{H}$ NMR (300 MHz, DMSO-d6), $\delta$; 4.14 and $4.53\left(\mathrm{dd}, 2 \mathrm{H},-\mathrm{CH}_{2} \mathrm{CH}(\mathrm{O}) \mathrm{CH}_{2} \mathrm{O}-, \mathrm{J}: 9.3 \mathrm{~Hz}\right) ; 4.85$ (m, $\left.1 \mathrm{H},-\mathrm{CH}_{2} \mathrm{CH}(\mathrm{O}) \mathrm{CH}_{2} \mathrm{O}-\right)$; 4.88 and $5.06\left(\mathrm{dd}, 2 \mathrm{H},-\mathrm{CH}_{2} \mathrm{CH}(\mathrm{O}) \mathrm{CH}_{2} \mathrm{O}-, \mathrm{J}: 11.7 \mathrm{~Hz}\right) ; 5.23\left(\mathrm{~s}, 2 \mathrm{H},-\mathrm{CH}_{2} \mathrm{C}_{10} \mathrm{H}_{7}\right) ; 6.81-8.56(\mathrm{~m}, 12 \mathrm{H}$, $\mathrm{Ar}-\mathrm{H}) ; 9.98$ (s, $1 \mathrm{H}, 2-\mathrm{CH}) .{ }^{13} \mathrm{C}$ NMR $\left(75 \mathrm{MHz}, \mathrm{DMSO}-\mathrm{d}_{6}\right) \delta ; 47.3\left(-\mathrm{CH}_{2} \mathrm{CH}(\mathrm{O}) \mathrm{CH}_{2} \mathrm{O}-\right) ; 50.2$ $\left(-\mathrm{CH}_{2} \mathrm{C}_{10} \mathrm{H}_{7}\right) ; 64.9\left(-\mathrm{CH}_{2} \mathrm{CH}(\mathrm{O}) \mathrm{CH}_{2} \mathrm{O}-\right) ; 68.9\left(-\mathrm{CH}_{2} \mathrm{CH}(\mathrm{O}) \mathrm{CH}_{2} \mathrm{O}-\right) ; 114.5,114.7,115.8,117.6$, $122.2,127.1,127.3,128.8,129.2,129.3,131.1,131.5,132.2,133.8,136.4,138.0$ and 142.3 (Ar-C); 144.2 (2-CH). Anal. Calc. for $\mathrm{C}_{27} \mathrm{H}_{23} \mathrm{ClN}_{2} \mathrm{O}_{2}$ : C: 73.21, H: 5.23, N: 6.32. Found C: 73.18, H: 5.25, N: 6.34 .

\subsection{DPPH assay.}

DPPH (2,2-diphenyl-1-picrylhydrazyl) free radical scavenging assay was used to determine of antioxidant activity of the tested compounds [44]. The tested compounds were dissolved in dimethyl sulfoxide (DMSO, $1 \mu \mathrm{g} / \mathrm{ml}$ ). $50 \mu 1$ of the compounds were mixed with DPPH solution in methanol $(0.1 \mathrm{mM})$. The absorbance values were read at $517 \mathrm{~nm}$ after $2 \mathrm{~h}$. As the standard, butylated hydroxytoluene (BHT) was used. The percentage inhibition was calculated by using a formula:

$\%$ Antioxidant activity (\%Inhibisyon) $=100 \times(1-$ Absorbance of test compound / Absorbance of control compound) (I)

\section{3. $\mathrm{H}_{2} \mathrm{O}_{2}$ scavenging activity.}

$\mathrm{H}_{2} \mathrm{O}_{2}$ scavenging effects of the synthesized compounds were measured according to Pick and Keisari [45]. $43 \mathrm{mM} \mathrm{H} \mathrm{H}_{2}$ was produced in phosphate buffer (0.1 M, pH 7.4). Compounds $(10 \mu \mathrm{g} / \mathrm{ml})$ in $3.4 \mathrm{ml}$ phosphate buffer were mixed with $\mathrm{H}_{2} \mathrm{O}_{2}$ solution. Absorbance was read at $230 \mathrm{~nm}$ after 10 minutes. The percentage of $\mathrm{H}_{2} \mathrm{O}_{2}$ scavenging activities of the compounds were calculated according to formula (I).

\subsection{Evaluation of antimicrobial activity.}

The eleven microorganisms were tested: Bacillus cereus FMC 19, Aeromonas hydrophila ATCC 7965, Escherichia coli ATCC 25922, E. coli O157:H7 932, Listeria monocytogenes 1/2B, Klebsiella pneumoniae FMC 5, Pseudomonas aeruginosa ATCC 27853, Salmonella typhimurium NRRLE 4463, Yersinia enterocolitica ATCC 1501 and Candida albicans ATCC 1223.

The antimicrobial activities of seven compounds ( 1 and $2 \mathrm{a}-\mathrm{f})$ were tested by the agarwell diffusion assay [46]. The compound solutions $(10 \mathrm{mg} / \mathrm{ml})$ were prepared in DMSO. The solution was sterilized through a membrane filter $(0.2 \mu \mathrm{m})$. The bacteria were grown in nutrient broth at $35^{\circ} \mathrm{C}$ for $18 \mathrm{~h}$, while malt extract for C. albicans at $25^{\circ} \mathrm{C}$ for $18 \mathrm{~h}$ was used. Cultures were adjusted to $0.5 \mathrm{McFarland}$ standard turbidity. Inoculated Mueller Hinton agar or malt extract agar was poured into Petri dishes. The Petri dishes were stored at $4{ }^{\circ} \mathrm{C}$ for $1 \mathrm{~h}$. The holes were made in the agar by sterile cork borers $(\varnothing=6 \mathrm{~mm})$. The solutions of compounds $(50 \mu \mathrm{l})$ were added to the holes. DMSO was used as a control. The bacteria were incubated at $35^{\circ} \mathrm{C}$ for 18-24 h ( $Y$. enterocolitica and $C$. albicans except). Inhibition zones were measured in millimeters. The standard antibiotics Tetracycline $(10 \mathrm{mg} / \mathrm{ml})$ (Sigma T3258-56) and Natamycin $(30 \mathrm{mg} / \mathrm{ml})$ (Delvocid DMS) were applied as positive control. 


\subsection{Computational studies.}

All density functional theory (DFT) calculations were exerted with the Discovery Studio (DS) 2020 program [47] to support the proposed activities for the antioxidant and antimicrobial activities of all compounds. The geometry of benzimidazolium salts was fully optimized with Becke3 (B3) Lee-Yang-Parr (LYP) method (B3LYP) using the DMol3 basis set in the gas phase. The HOMO-LUMO analysis and molecular electrostatic potential surface (MESP) are employed to obtain important insights into the atomic level compounds.

\section{Results and Discussion}

\subsection{Synthesis and characterization study.}

The 1-(2-methyl-1,4-benzodioxane)benzimidazole 1 was synthesized using the benzimidazole 2-bromomethyl-1,4-benzodioxane, and it was obtained in yield $80 \%$. This compound has been illustrated in Scheme 1. The 2-methyl-1,4-benzodioxane substituted benzimidazolium salts 2a-f were synthesized using the common alkylation assay and were obtained in moderate yields between $68-83 \%$. The air and moisture stable benzimidazolium salts were soluble in polar solvents such as water, alcohol, and dimethyl sulfoxide. But all compounds were less-soluble in halogenated solvents such as dichloromethane and chloroform. The benzimidazolium salts 2a-f have been illustrated in Scheme 2. The synthesized salts' structures were characterized by using FT-IR, ${ }^{1} \mathrm{H}$ NMR, ${ }^{13} \mathrm{C}$ NMR spectroscopic methods, and elemental analysis techniques. In the ${ }^{1} \mathrm{H}$ NMR spectra, the benzimidazolium salts were detected by a characteristic proton peak at the 2-position $(\mathrm{NCHN})$ of the benzimidazolium salts 2a-f, which appeared highly downfield shifted singleds at $\delta 11.48$, $11.40,11.46,9.62,10.06$ and 9.98 ppm for 2a-f, respectively. Multiplets in the range $\delta$ between 6.52 and 8.95 were attributed to aromatic protons. In the ${ }^{13} \mathrm{C} \mathrm{NMR}$ spectra of the benzimidazolium salts 2a-f, a carbon signal in the range $\delta$ 142.9-143.4 was attributed to NCHN carbon at a lower area compared to other aromatic carbons at 143.4, 142.9, 143.2, 143.2, 143.0, and 144.2 for $\mathbf{2 a - f}$, respectively. FT-IR spectra of the benzimidazolium salts showed a band at $1501,1560,1558,1560,1567,1561$, and $1563 \mathrm{~cm}^{-1}$ corresponding to the vibrations of $\mathrm{C}=\mathrm{N}$ of the 1-(2-methyl-1,4-benzodioxane) benzimidazole 1 and benzimidazolium salts 2a-f, respectively. All spectroscopic data of the compounds are consistent with the literature [23$25,29,33]$.

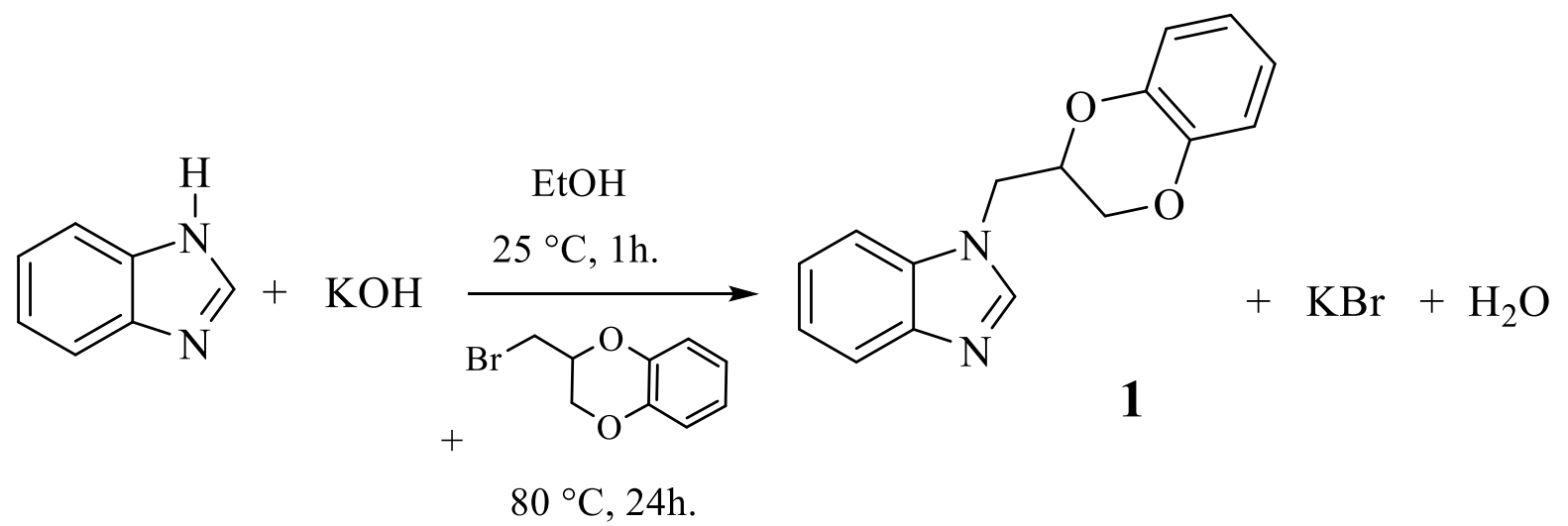

Scheme 1. 1-(2-methyl-1,4-benzodioxane) benzimidazole, 1. 


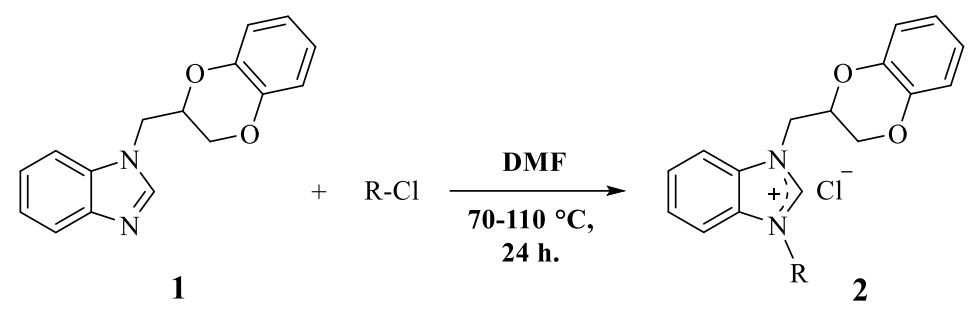

R:

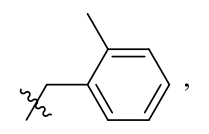

a

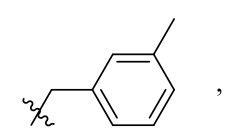

b

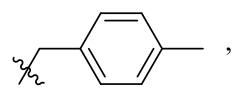

c

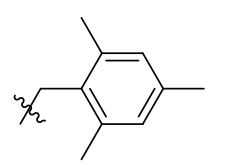

d

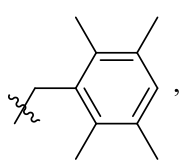

e

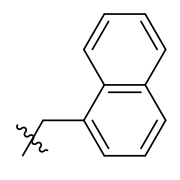

f

Scheme 2. Synthesis of novel 2-methyl-1,4-benzodioxane-substituted benzimidazolium salts 2a-f.

\subsection{In vitro antioxidant activity study.}

Newly synthesized compounds experimented with free radical scavenging ability. BHT was used as a standard compound. The results of the DPPH radical scavenging activities of the compounds are summarized in Table 1 and Fig. 1. We found that all of the compounds showed moderate free radical-scavenging activities. All compounds exhibited DPPH scavenging activity in the range of $30.85-39.75 \%$ as compared to BHT $(91.47 \%)$. The maximum free radical scavenging activity was found as $39.75 \%$ for compound $2 \mathrm{f}$ at $1 \mathrm{mg} / \mathrm{ml}$, while the least activity was calculated for 2 a $(30.85 \%)$. This study reveals that substitution with electrondonating groups, which may lead to free radical quenching, increases the antioxidant potential. It can be said that the presence of the 2-methyl-1,4-benzodioxane substituent on the compounds contributes to this effect, too. Also, it is observed that the effect of inhibition increases as the methyl number increases of benzyl substituent groups on the benzimidazolium salts. In a similar study, Haque et al. worked on para-xylyl linked bis-benzimidazolium salts' antioxidant activities and respective dinuclear Ag-NHC complexes by using DPPH assay and found their \%inhibition values in the range of 6.37-21.00 [15]. The \%inhibition values which we get in our work are higher than this work.

\section{3. $\mathrm{H}_{2} \mathrm{O}_{2}$ scavenging activity study.}

All synthesized compounds tested for hydrogen peroxide scavenging activity. The activities of test compounds to scavenge $\mathrm{H}_{2} \mathrm{O}_{2}$ are given in Table 1 and Fig. 1, and compared with that of BHA, BHT, and Gallic acid as standard compounds. All compounds exhibited strong hydrogen peroxide scavenging activity ranges between 121.16 and $143.54 \%$ at 10 $\mu \mathrm{g} / \mathrm{ml}$. BHA, BHT, and Gallic acid exhibited 18.526 .67 and 30.09\% inhibition, respectively, at the same concentration. The synthesized compounds have more potential $\mathrm{H}_{2} \mathrm{O}_{2}$ scavenging activity compared with those of the standards. These activities may be due to the presence of electron-donating methyl groups on the benzene ring.

\subsection{Antimicrobial activity study.}

The antimicrobial effects of the tested compounds were examined against nine bacteria and yeast. Compounds showed varying degrees of antimicrobial effect against all of the tested microorganisms. Especially, they showed strong activity against Pseudomonas aeruginosa, Listeria monocytogenes, and C. albicans (growth inhibition zones $\geq 18 \mathrm{~mm}$ ) (Table 2 - Fig. 2). Among all compounds, the 1-(2-methyl-1,4-benzodioxan)benzimidazole 1 exerted the least 
antibacterial effect against all the studied bacteria, with the inhibition zones ranging from 9.0 $\mathrm{mm}$ to $14 \mathrm{~mm}$. This compound had no inhibitory activity against $A$. hydrophila, E. coli, and $S$. typhimurium. While compound $2 \mathbf{e}$ having tetramethyl groups exhibited the strongest antibacterial activity against one or more tested bacteria $(12-26 \mathrm{~mm})$, the tetracycline exhibited antibacterial effect against all the studied bacteria with the inhibition zones ranging from 16 $\mathrm{mm}$ to $27 \mathrm{~mm}$. All compounds except 1 exhibited strong activity against L. monocytogenes and P. aeruginosa (inhibition zones $\geq 18 \mathrm{~mm}$ ) (Table 2 - Fig. 2-3). Compound 1 was inactive against A. hydophila, E. coli, and $S$. typhimurium. Compounds $\mathbf{2 b}$ and $\mathbf{2 d}$ showed the same inhibitor activity, while compound $\mathbf{2 e}$ had stronger activity against $L$. monocytogenes than standard tetracycline. Also, compound $2 \mathbf{f}$ containing naphthalenomethyl substituent showed the same inhibitor activity while compounds $\mathbf{2} \mathbf{d}$ and $\mathbf{2 e}$ containing three and tetramethyl groups had stronger activity against $P$. aeruginosa compared with standard tetracycline (Table $2-$ Fig. 2).

The compounds 2 a-f exhibited weak activity against $A$. hydophila and S. typhimurium (10-13 $\mathrm{mm}$ and 9-12 $\mathrm{mm}$, respectively). While the compound $\mathbf{2 e}$ containing tetramethyl groups exhibited moderate activity, other tested compounds exhibited weak activity against $Y$. enterocolitica $(0.9-11 \mathrm{~mm})$. All compounds except 1 exhibited a moderate or weak effect on E. coli (10-14 mm). E. coli $\mathrm{O} 157: \mathrm{H} 7$ and $K$. pneumoniae are sensitive to all of the test compounds with the inhibition zones ranging from $0.9 \mathrm{~mm}$ to $19 \mathrm{~mm}$ and from $10 \mathrm{~mm}$ to 19 $\mathrm{mm}$, respectively (Table 2 - Fig. 2). When the antibacterial activity of all compounds examined, the compounds $\mathbf{2 d}$ and $\mathbf{2 f}$ exhibited higher antibacterial activity $(14 \mathrm{~mm})$ than compounds $\mathbf{2 a}, \mathbf{2 b}, \mathbf{2 c}, \mathbf{2 e}(13 \mathrm{~mm})$, and compound $1(10 \mathrm{~mm})$ against B. cereus (Table $2-$ Fig. 3 ). When the benzimidazolium salts (2a-f) containing aromatic groups compared with similar benzimidazolium salts [33] containing aliphatic groups exhibited higher activity against Gram (+) and Gram (-) bacteria.

The compounds $\mathbf{1}$ and 2a-f had a more potential effect with either high or equal inhibition zones than standard natamycin against $C$. albicans (Table 2 - Fig. 4). According to the results, the tested compounds' antimicrobial activities against bacteria and yeast vary due to structural differences between the microorganisms and compounds. On the other hand, the existence of the electron-donating methyl groups existing on the benzene ring generally has increased the antibacterial activity. The many benzimidazole-based compounds have exhibited biological activity due to bearing functional groups at the 1, 2, and/or 5, 6 positions [48]. It has been previously reported that $\mathrm{N}$-morpholinoethylbenzimidazole and 2-morpholinoethylsubstituted benzimidazolium salts have exhibited strong antimicrobial activity against E.coli and $S$. aureus [13].

Table 1. Inhibitory effect of the compounds 1 and 2a-f on DPPH radical and $\mathrm{H}_{2} \mathrm{O}_{2}$.

\begin{tabular}{|c|c|c|}
\hline & DPPH & $\mathrm{H}_{2} \mathrm{O}_{2}$ \\
\hline Compounds & $\%$ Inhibition $^{*}$ & $\%$ Inhibition \\
\hline 1 & 29.53 & 136.46 \\
\hline $2 \mathbf{a}$ & 30.85 & 143.54 \\
\hline $2 \mathbf{b}$ & 32.27 & 121.50 \\
\hline $2 c$ & 31.14 & 121.16 \\
\hline 2d & 33.01 & 127.76 \\
\hline $2 e$ & 34.33 & 122.38 \\
\hline $2 f$ & 39.75 & 124.86 \\
\hline BHT & 91.47 & 6.67 \\
\hline BHA & - & 18.52 \\
\hline Gallic acid & - & 30.09 \\
\hline
\end{tabular}


Table 2. Antimicrobial activities of compounds 1, 2a-f, and reference drug against the tested microorganisms.

\begin{tabular}{|c|c|c|c|c|c|c|c|c|}
\hline \multirow{2}{*}{ Organisms } & \multicolumn{7}{|c|}{ Compounds } & \multirow{2}{*}{$\frac{\text { Tetracycline }}{(10 \mu \mathrm{g} / \mathrm{ml})}$} \\
\hline & 1 & $2 a$ & $2 \mathbf{b}$ & $2 c$ & 2d & $2 \mathrm{e}$ & $2 f$ & \\
\hline \multicolumn{9}{|l|}{ Gram (-) } \\
\hline A. hydrophila & - & 10 & 13 & 12 & 11 & 12 & 11 & 22.0 \\
\hline E. coli & - & 13 & 13 & 14 & 12 & 13 & 12 & 21.0 \\
\hline E. coli $\mathrm{O} 157: \mathrm{H} 7$ & $9^{*}$ & 13 & 13 & 19 & 14 & 14 & 16 & 21.0 \\
\hline K. pneumoniae & 10 & 14 & 18 & 16 & 17 & 19 & 15 & 23.0 \\
\hline P. aeruginosa & 14 & 19 & 19 & 19 & 22 & 22 & 21 & 21.0 \\
\hline S. typhimurium & - & 9 & 12 & 12 & 11 & 12 & 11 & 16.0 \\
\hline Y. enterocolitica & 10 & 10 & 9 & 11 & 11 & 14 & 11 & 27.0 \\
\hline \multicolumn{9}{|l|}{ Gram (+) } \\
\hline B. cereus & 10 & 13 & 13 & 13 & 14 & 13 & 14 & 26.0 \\
\hline L. monocytogenes & 11 & 18 & 21 & 20 & 21 & 26 & 19 & 21.0 \\
\hline Yeast & & & & & & & & $\begin{array}{l}\text { Natamycin } \\
(30 \mu \mathrm{g} / \mathrm{ml})\end{array}$ \\
\hline C. albicans & 28 & 19 & 24 & 31 & 26 & 26 & 23 & 24.0 \\
\hline
\end{tabular}

*: inhibition zones include the diameter of the hole $(6 \mathrm{~mm})$. Sample amount $50 \mu \mathrm{l}$.

-: Not active

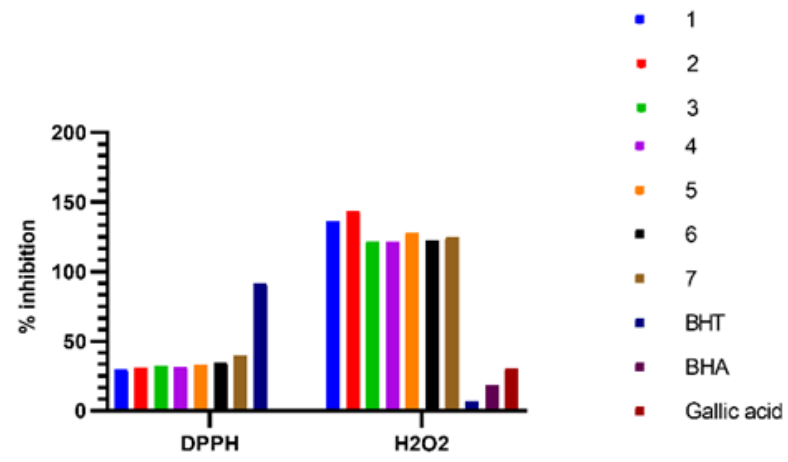

Figure 1. Inhibitory effect of the compounds 1 and $2 \mathrm{a}-\mathrm{f}$ on DPPH radicals and $\mathrm{H}_{2} \mathrm{O}_{2}$.

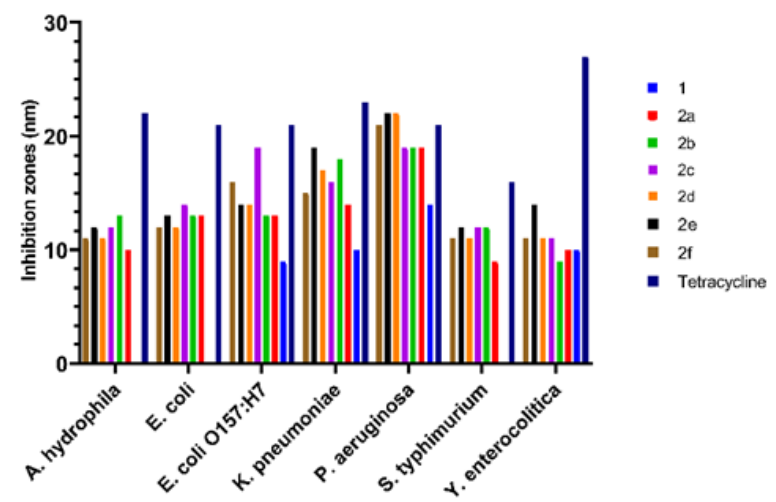

Figure 2. Antibacterial activities of the compounds 1, 2a-f and reference drug (Tetracycline) against the tested Gram (-) bacteria.

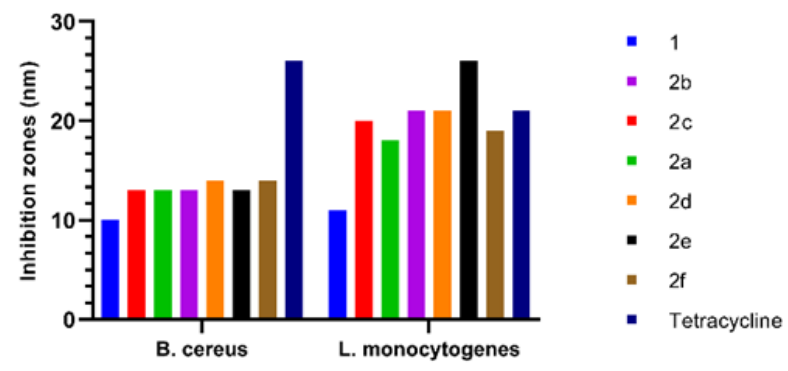

Figure 3. Antibacterial activities of the compounds 1, 2a-f and reference drug (Tetracycline) against the tested Gram (+) bacteria. 


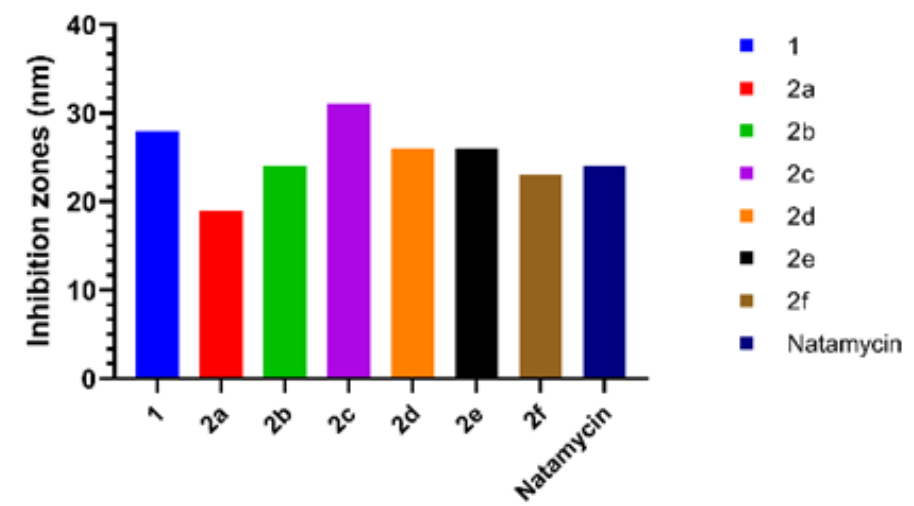

Figure 4. Anticandidal activities of the compounds 1, 2a-f and reference drug (Natamycin) against the $C$. albicans

\subsection{Computational results.}

In this study, besides the experimental studies of benzimidazolium salts, theoretical calculations were applied to elucidate the compounds' relevant parts in the applied activity techniques. Therefore, the benzimidazolium salt structures are geometrically and energetically optimized at the DFT / B3LYP / DMol3 level to predict the boundary molecular orbitals and electronic structure benzimidazolium salts using DS program. The highest occupied molecular orbital (HOMO) energy, EHOMO, the lowest unoccupied molecular orbital (LUMO) energy, ELUMO, energy gap, Egap values, and views for benzimidazolium salts, obtained by the same method are displayed in Figure 5 and Figure 6, respectively. Red and green colors exhibit the positive and negative phases, respectively. The HOMO-LUMO energy gap values of benzimidazolium salt, as remarked bold red color in Figure 5, are 5.694, 4.635, 3.403, 3.169, $4.819,3.521$, and $2.893 \mathrm{eV}$, respectively. These results show us why which compound exhibits better activity than other compounds.

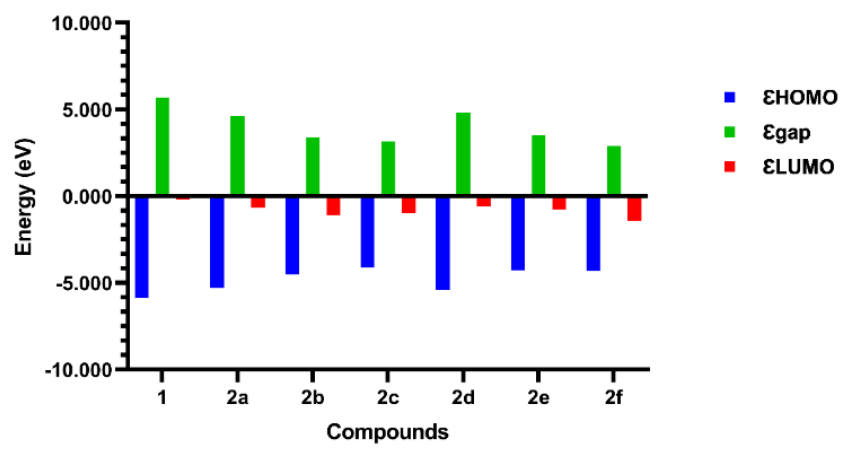

Figure 5. The calculated EHOMO, ELUMO, and Egap values of all compounds, respectively.

Furthermore, the molecular electrostatic potential surface (MESP) was calculated to investigate benzimidazolium salts' electron density. Generated MEPS map shows the relation between molecular structure and physicochemical property of benzimidazolium salts (Figure 7). Different colors show and visualize different electrostatic potentials at the surface of the structure. The region of attractive potential appears in red. Those of repulsion potential appear in blue. Thus, the $\mathrm{Cl}$ and $\mathrm{O}$ atoms regions have higher positive electrostatic potential and participate in nucleophilic reactions. $\mathrm{N}$ atoms with higher electronegative values have higher electron density around them and participate in electrophilic attacks. 


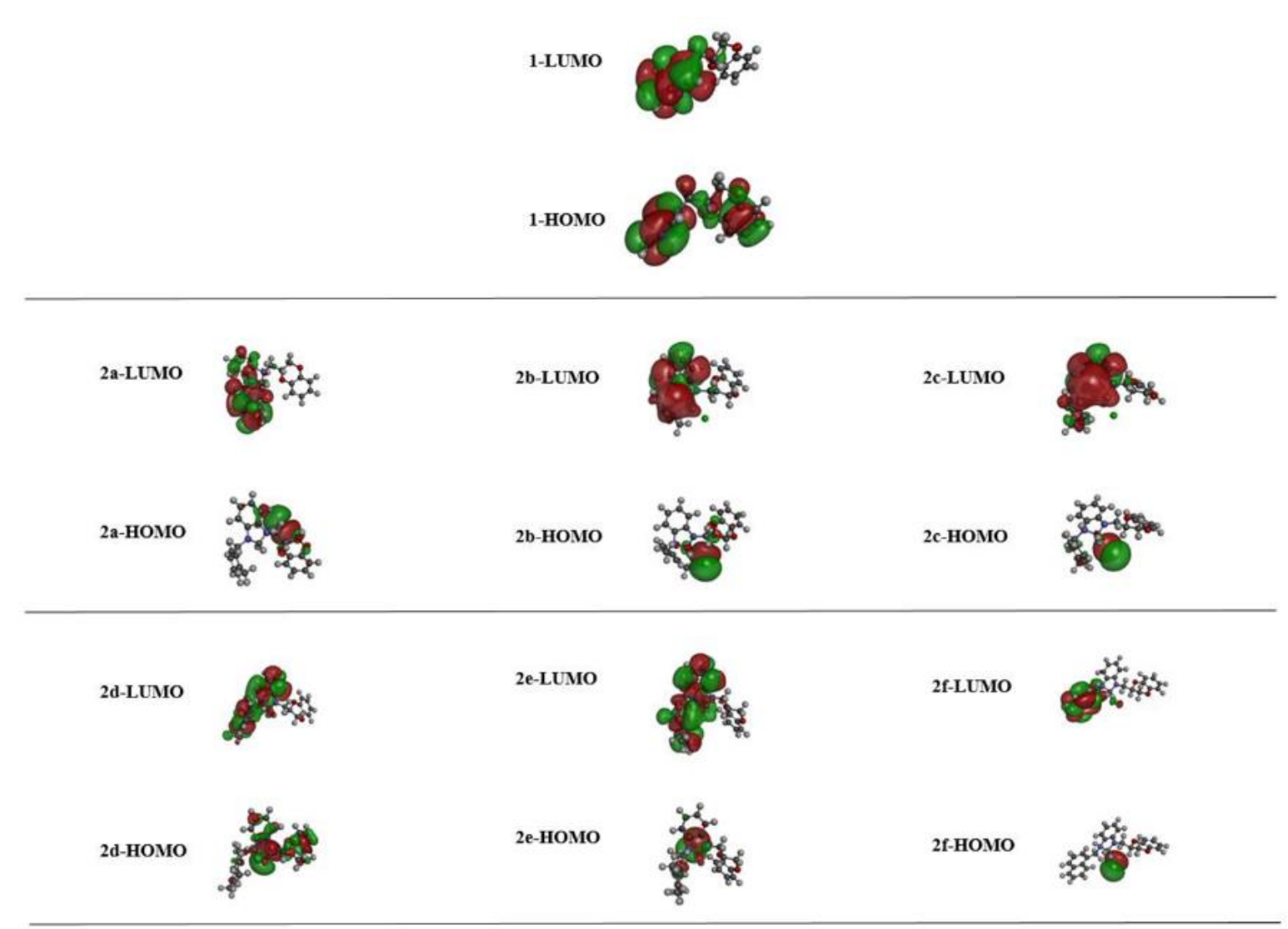

Figure 6. The pictorial image of HOMO and LUMO frontier molecular orbitals for benzimidazolium salts is calculated using the B3LYP method with a DMol3 basis set.

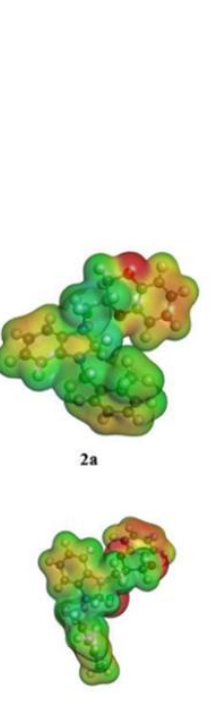

$2 \mathrm{~d}$
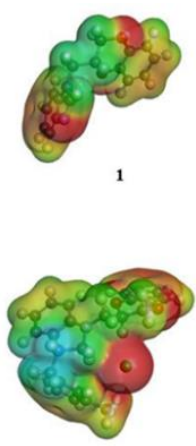

2b

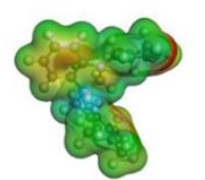

$2 \mathrm{e}$

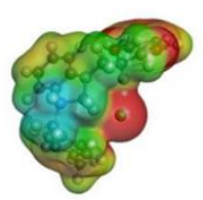

$2 \mathrm{c}$

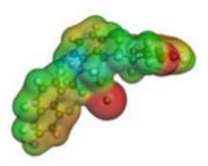

2f

Figure 7. The electron density isosurface for benzimidazolium salts calculated by B3LYP method with DMol3 basis set.

\section{Conclusions}

In conclusion, this study contains the synthesis and characterization of the $\mathrm{N}$-substituted benzimidazole and six new benzimidazolium salts. DPPH and $\mathrm{H}_{2} \mathrm{O}_{2}$ scavenging abilities of all compounds were examined. All compounds exhibited moderate free radical-scavenging activity but strong hydrogen peroxide scavenging activity. Synthesized compounds exhibited varying degrees of antimicrobial activity against all tested microorganisms, especially against Pseudomonas aeruginosa, Listeria monocytogenes and C. albicans. The antioxidant and 
antimicrobial activities of the synthesized benzimidazolium salts are very promising. Besides these applied studies, computational applications HOMO-LUMO analysis and molecular electrostatic potential surface (MESP) were probed using DS 2020. Obtained results from the present study will contribute to further study in this field. Further optimizations and detailed SAR studies are needed.

\title{
Funding
}

This research was funded by Inonu University Research Fund, grant number 2011/21.

\section{Acknowledgments}

\begin{abstract}
The authors acknowledge Inonu University Scientific and Technology Center for the elemental analyses and the characterization of compounds.
\end{abstract}

\section{Conflicts of Interest}

The authors declare no conflict of interest.

\section{References}

1. Crabtree, R.H. Some chelating C-donor ligands in hydrogen transfer and related catalysis. J. Organomet. Chem. 2006, 691, 3146-3150, https://doi.org/10.1016/j.jorganchem.2006.01.032.

2. Garrison, J.C.; Youngs, W.J. Ag(I)N-Heterocyclic Carbene Complexes: Synthesis, Structure, and Application. Chem. Rev. 2005, 105, 3978-4008, https://doi.org/10.1021/cr050004s.

3. Sarı, Y.; Aktaş, A.; Barut Celepci, D.; Gök, Y.; Aygün, M. Synthesis, Characterization and Crystal Structure of New 2-Morpholinoethyl-Substituted Bis-(NHC)Pd(II) Complexes and the Catalytic Activity in the Direct Arylation Reaction. Catal Lett 2017, 147, 2340-2351, https://doi.org/10.1007/s10562-017-2132-3.

4. Despagnet-Ayoub, E.; Grubbs, R.H. A Stable Four-Membered N-Heterocyclic Carbene. J Am Chem Soc 2004, 126, 10198-10199, https://doi.org/10.1021/ja047892d.

5. Arduengo III, A.J.; Dias, H.V.R.; Harlow, R.L.; Kline, M. Electronic stabilization of nucleophilic carbenes. J Am Chem Soc. 1992, 114, 5530-5534, https://doi.org/10.1021/ja00040a007.

6. Liu, Y.; Lemal, D.M. Concerning the 'Wanzlick equilibrium'. Tetrahedron Lett. 2000, 41, 599-602, https://doi.org/10.1016/S0040-4039(99)02161-9.

7. Hahn, F.E.; Wittenbecher, L.; Boese, R.; Blaser, D. N,N'-Bis(2,2-dimethylpropyl)benzimidazolin-2-ylidene: A Stable Nucleophilic Carbene Derived from Benzimidazole. Chem-Eur J. 1999, 5, 1931-1935, https://doi.org/10.1002/(SICI)1521-3765(19990604)5:6<1931::AID-CHEM1931>3.0.CO;2-M.

8. Bazinet, P.; Ong, T-G.; O’Brien, J.S. Lavoie, N.; Bell, E.; Yap, G.P.A.; Korobkov, I.; Richeson, D.S. Design of Sterically Demanding, Electron-Rich Carbene Ligands with the Perimidine Scaffold. Organometallics 2007, 26, 2885-2895, https://doi.org/10.1021/om0701827.

9. Kolychev, E.L.; Portnyagin, I.A.; Shuntikov, V.V. Khrustalev, V.N.; Nechaev, M.S. Six-and sevenmembered ring carbenes: Rational synthesis of amidinium salts, generation of carbenes, synthesis of Ag (I) and $\mathrm{Cu}$ (I) complexes. J Organomet Chem. 2009, 694, 2454-2462, https://doi.org/10.1016/j.jorganchem.2009.03.014.

10. Kamal, A.; Nagaseshadri, B.; Nayak, V.L.; Srinivasulu, V.; Sathish, M.; Kapure, J.S. Reddy, C.S. Synthesis and biological evaluation of benzimidazole-oxindole conjugates as microtubule-targeting agents. Bioorganic Chem 2015, 63, 72-84, https://doi.org/10.1016/j.bioorg.2015.09.003.

11. Gavisiddegowda, P.; Kollur, S.P.; ibrahim, S.; Revanasiddappa H.D. Novel Benzimidazole Derived ImineBased Ligand and its $\mathrm{Co}(\mathrm{III}), \mathrm{Ni}(\mathrm{II}), \mathrm{Cu}(\mathrm{II})$ and $\mathrm{Pt}(\mathrm{II})$ Complexes: Chemical Synthesis, Structure, Antimicrobial, DNA Interaction Studies and Nuclease Activity Letters in Applied NanoBioScience 2020, 9 , 1655-1672, https://doi.org/10.33263/LIANBS94.16551672.

12. Akkoç, S.; Tüzün, B.; İlhan, Ö.İ.; Akkurt, M. Investigation of structural, spectral, electronic, and biological properties of 1,3-disubstituted benzimidazole derivatives Journal of Molecular Structure 2020, 1219, https://doi.org/10.1016/j.molstruc.2020.128582

13. Yıldırım, I.; Aktaş, A.; Barut Celepci, D.; Kırbağ, S.; Kutlu, T.; Gök Y.; Aygün, M. Synthesis, characterization, crystal structure, and antimicrobial studies of 2-morpholinoethyl-substituted benzimidazolium salts and their silver(I)-N-heterocyclic carbene complexes. Res Chem Intermed 2017, 43, 6379-6393, https://doi.org/10.1007/s11164-017-2995-3 
14. Tessier, J.; Lecluse, M.; Gravel, J.; Schmitzer, A.-R. Antimicrobial and Antibiofilm Activity of Disubstituted Bis-benzimidazolium Salts. ChemMedChem. 2018, 13,2567-2572,https://doi.org/10.1002/cmdc.201800639.

15. Küçükbay, H.; Durmaz, R.; Orhan, E.; Günal, S. Synthesis, antibacterial and antifungal activities of electronrich olefins derived benzimidazole compounds. Il Farmaco 2003, 58, 431-437, https://doi.org/10.1016/S0014-827X(03)00068-5.

16. Garuti, L.; Roberti, M.; Gentilomi, G. Synthesis and antiviral assays of some benzimidazole nucleosides and acyclonucleosides Il Farmaco 2001, 56, 815-819, https://doi.org/10.1016/S0014-827X(01)01164-8.

17. Haque, R.A.; Iqbal, M.A.; Asekunowo, P.; Majid, A.M.S.A.; Ahamed, M.B.K.; Umar, M.I.; Al-Rawi, S.S.; Al-Suede, F.S.R. Synthesis, structure, anticancer, and antioxidant activity of para-xylyl linked bisbenzimidazolium salts and respective dinuclear $\mathrm{Ag}(\mathrm{I}) \mathrm{N}$-heterocyclic carbene complexes (Part-II). Med Chem Res 2013, 22, 4663-4676, https://doi.org/10.1007/s00044-012-0461-8.

18. Rodríguez-Sanz, A.; Sanchez-Alonso, P.; Bellon, T.; Alajarín, R.; Martínez-Cabeza, V.; Selgas, R.; Vaquero, J.J.; Alvarez-Builla, J. Synthesis and biological evaluation of pyridazino [1', 6': 1, 2] pyrido [3, 4-b] indolinium and pyridazino [1, 6-a] benzimidazolium salts as anti-inflammatory agents. Eur J Med Chem 2015, 93, 83-92, https://doi.org/10.1016/j.ejmech.2015.01.060.

19. Aktaş, A.; Keleştemur, Ü.; Gök, Y.; Balcığlu, S.; Ateş, B.; Aygün, M. 2-Morpholinoethyl-substituted Nheterocyclic carbene (NHC) precursors and their silver(I)NHC complexes: synthesis, crystal structure and in vitro anticancer properties J Iran Chem Soc 2018, 15, 131-139, https://doi.org/10.1007/s13738-017-12168.

20. Karataş, M.O.; Tekin, S.; Alıcı, B.; Sandal, S. Cytotoxic effects of coumarin substituted benzimidazolium salts against human prostate and ovarian cancer cells. J Chem Sci 2019, 131, https://doi.org/10.1007/s12039019-1647-0.

21. Eren, G.; Y1lmaz, S.; Gümüş, F. In Vitro Cytotoxic Activities of Platinum (II) Complex with 1-Methyl-2(3'-hydroxypropyl) benzimidazole and 2-(3\#39;-Hydroxypropyl) benzimidazolium Hexa-and Tetrachloroplatinate Salts. Lett Drug Des Discovery 2018, 15, 65-69, https://doi.org/10.2174/1570180814666171012163325.

22. Sarı, Y.; Aktaş, A.; Taslimi, P.; Gök, Y.; Gülçin, İ. Novel N-propylphthalimide- and 4-vinylbenzylsubstituted benzimidazole salts: Synthesis, characterization, and determination of their metal chelating effects and inhibition profiles against acetylcholinesterase and carbonic anhydrase enzymes J Biochem Mol Toxicol 2017, 32, https://doi.org/10.1002/jbt.22009.

23. Erdemir, F.; Barut Celepci, D.; Aktaş, A.; Taslimi, P.; Gök, Y.; Karabıyık, H.; Gülçin, İ. 2-Hydroxyethyl substituted NHC precursors: Synthesis, characterization, crystal structure and carbonic anhydrase, $\alpha$ glycosidase, butyrylcholinesterase, and acetylcholinesterase inhibitory properties. J Mol Struct 2018, 1155, 797-806, https://doi.org/10.1016/j.molstruc.2017.11.079.

24. Türker, F.; Barut Celepci, D.; Aktaş, A.; Taslimi, P.; Gök, Y.; Aygün, M.; Gülçin, İ. meta-Cyanobenzyl substituted benzimidazolium salts: Synthesis, characterization, crystal structure and carbonic anhydrase, $\alpha$ glycosidase, butyrylcholinesterase, and acetylcholinesterase inhibitory properties. Arch Pharm Chem Life Sci 2018, 351, https://doi.org/10.1002/ardp.201800029.

25. Behçet, A.; Çağlılar, T.; Barut Celepci, D.; Aktaş, A.; Taslimi, P.; Gök, Y.; Aygün, M.; Kaya, R.; Gülçin, İ. Synthesis, characterization and crystal structure of 2-(4-hydroxyphenyl)ethyl and 2-(4-nitrophenyl)ethyl Substituted Benzimidazole Bromide Salts: Their inhibitory properties against carbonic anhydrase and acetylcholinesterase. J Mol Struct 2018, 1170, 160-169, https://doi.org/10.1016/j.molstruc.2018.05.077.

26. Aktaş, A.; Ali, N.S.A.; Barut Celepci, D.; Erdemir, F.; Gök, Y.; Ateş, B. New 2-hydroxyethyl substituted NHeterocyclic carbene precursors: Synthesis, characterization, crystal structure and inhibitory properties against carbonic anhydrase and xanthine oxidase. J Mol Struct 2019, 1184, 487-494, https://doi.org/10.1016/j.molstruc.2019.02.063.

27. Kazanc1, A.; Gök, Y.; Kaya, R.; Aktaş, A.; Taslimi, P.; Gülçin, İ. Synthesis, characterization and bioactivities of dative donor ligand N-heterocyclic carbene (NHC) precursors and their $\mathrm{Ag}(\mathrm{I}) \mathrm{NHC}$ coordination compounds. Polyhedron 2021, 193, https://doi.org/10.1016/j.poly.2020.114866.

28. He, Y.; Wu, B.; Yang, J.; Robinson, D.; Risen, L.; Ranken, R.; Blyn, L.; Sheng, S.; Swayze, E.E. 2-Piperidin4-yl-benzimidazoles with broad spectrum antibacterial activities. Bioorgan Med Chem Lett 2003, 13, 32533256, https://doi.org/10.1016/S0960-894X(03)00661-9.

29. He, Y.; Yang, J.; Wu, B.; Risen, L.; Swayze, E.E. Synthesis and biological evaluations of novel benzimidazoles as potential antibacterial agents. Bioorgan Med Chem Lett 2004, 14, 1217-1220, https://doi.org/10.1016/j.bmcl.2003.12.051.

30. Al-Romaizan, A.N. Synthesis and antitumor activity of new isolated and fused heterobicyclic nitrogen systems containing 1,3,4-thiadiazole moiety derived from N1,N2-diaryl hydrazine compound. Letters in Applied NanoBioScience 2020, 9, 935-940, https://doi.org/10.33263/LIANBS91.935940.

31. Wang, De-Pu.; Liu, Kai-Li.; Li, Xin-Yang.; Lu, Guo-Qing.; Xue, Wen-Han.; Qian, Xin-Hua.; Mohamed O, K.; Meng F.-H. Design, synthesis, and in vitro and in vivo anti-angiogenesis study of a novel vascular endothelial growth factor receptor-2 (VEGFR-2) inhibitor based on 1,2,3-triazole scaffold European Journal of Medicinal Chemistry 2021, 211, https://doi.org/10.1016/j.ejmech.2020.113083. 
32. Singh, A.; Sharma, S.; Kaur, N.; Singh, N. Self-assembly of imidazolium/benzimidazolium cationic receptors: their environmental and biological applications New J. Chem. 2020, 44, 19360-19375, https://doi.org/10.1039/D0NJ03836A

33. Gök, Y.; Akkoç, S.; Erdogan, H.; Albayrak, S. In vitro antimicrobial studies of new benzimidazolium salts and silver N-heterocyclic carbene complexes. J Enzym Inhib Med Chem 2016, 31, 1322-1327, https://doi.org/10.3109/14756366.2015.1132210.

34. Akkoç, S.; Gök, Y.; Erdoğan, H.; Albayrak, S. Biological Activity Evaluation Of Novel N-Heterocyclic Carbene Precursors. Int J Pharm Sci Res 2017, 8, 262-267, https://doi.org/10.13040/IJPSR.09758232.8(1).262-67.

35. Sarı, Y.; Akkoç, S.; Gök, Y.; Sifniotis, V.; Özdemir, İ.; Günal, S.; Kayser, V. Benzimidazolium-based novel silver N-heterocyclic carbene complexes: synthesis, characterisation and in vitro antimicrobial activity. $J$ Enzyme Inhib Med Chem 2016, 31, 1527-1530, https://doi.org/10.3109/14756366.2016.1156102.

36. Behçet, A.; Aktaş, A.; Gök, Y.; Kaya, R.; Taslimi, P.; Gülçin İ. Novel Silver(I)N-Heterocyclic Carbene Complexes Bearing 2-(4-hydroxyphenyl)ethyl Group: Synthesis, Characterization and Enzyme Inhibition Properties. Journal of Heterocyclic Chemistry 2021, https://doi.org/10.1002/jhet.4199.

37. Kutlu, T.; Yıldırım, I.; Karabıyık, H.; Kılınçlı, A.; Tekedereli, İ.; Gök, Y.; Dikmen, M.; Aktaş, A. Cytotoxic Activity and Apoptosis Induction by A Series Ag(I)NHC Complexes on Human Breast Cancer Cells and Non-Tumorigenic Epithelial Cell Line. Journal of Molecular Structure 2020, https://doi.org/10.1016/j.molstruc.2020.129462.

38. Aktaş, A.; Barut Celepci, D.; Gök, Y.; Taslimi, P.; Akıncıoğlu, H.; Gülçin, İ. A Novel Ag-N-heterocyclic Carbene Complex Bearing the Hydroxyethyl Ligand: Synthesis, Characterization, Crystal and Spectral Structures and Bioactivity Properties. Crystals 2020, 10, https://doi.org/10.3390/cryst10030171.

39. Daşgın, S.; Gök, Y.; Barut Celepci, D.; Taslimi, P.; İzmirli, M.; Aktaş, A.; Gülçin, İ. Synthesis, Characterization, Crystal Structure and Bioactivity Properties of the Benzimidazole-Functionalized PEPPSI Type of $\mathrm{Pd}(\mathrm{II}) \mathrm{NHC}$ Complexes. Journal of Molecular Structure 2020, 1228, https://doi.org/10.1016/j.molstruc.2020.129442.

40. Türker, F.; Noma, S.A.A.; Aktaş, A.; Al-Khafaji, K.; Taşkın Tok, T.; Ateş, B.; Gök, Y. The (NHC)PdBr $2(2-$ aminopyridine) Complexes: Synthesis, Characterization, Molecular Docking Study and Inhibitor Effects on the Human Serum Carbonic Anhydrase and Serum Bovine Xanthine Oxidase. Monatshefte für Chemie Chemical Monthly 2020, 151, 1557-1567, https://doi.org/10.1007/s00706-020-02687-2.

41. Türker, F.; Gürses, C.; Barut Celepci, D.; Aktaş, A.; Ateş, B.; Gök, Y. New Morpholine Liganded Palladium(II) N-heterocyclic Carbene Complexes: Synthesis, Characterization, Crystal Structure and DNA Binding Studie. Arch Pharm Chem Life Sci. 2019, 352, https://doi.org/10.1002/ardp.201900187.

42. Erdemir, F.; Barut Celepci, D.; Aktaş, A.; Gök, Y.; Kaya, R.; Taslimi, P.; Demir, Y.; Gulçin, İ. Novel 2aminopyridine liganded Pd(II)N-Heterocyclic Carbene Complexes: Synthesis, Characterization, Crystal Structure and Bioactivity Properties. Bioorganic Chemistry 2019, 91, https://doi.org/10.1016/j.bioorg.2019.103134.

43. Aktaş, A.; Barut Celepci, D.; Kaya, R.; Taslimi, P.; Gök, Y.; Aygün, M.; Gülçin, İ. Novel morpholine liganded Pd-based N-heterocyclic carbene complexes: Synthesis, characterization, crystal structure, antidiabetic and anticholinergic properties. Polyhedron 2019, 159, 345-354.

44. Lee, S.K.; Mbwambo, Z.H.; Chung, H.S.; Luyengi, L.; Games, E.J.C.; Metha, R.G.; Kinghorn, A.D.; Pezzuto, J.M. Evaluation of the antioxidant potential of natural products. Comb Chem High Throughput Screening 1998, 1, 35-46.

45. Pick, E.; Keisari, Y. A simple colorimetric method for the measurement of hydrogen peroxide produced by cells in culture. J Immunol Methods 1980, 38, 161-170, https://doi.org/10.1016/0022-1759(80)90340-3

46. Seenaiah, D.; Reddy, P.R.; Reddy, G.M.; Padmaja, A.; Padmavathi, V.; Krishna, N.S. Synthesis, antimicrobial and cytotoxic activities of pyrimidinyl benzoxazole, benzothiazole and benzimidazole. Eur $J$ Med Chem 2014, 77, 1-7, https://doi.org/10.1016/j.ejmech.2014.02.050.

47. BIOVIA D S 2016. Dassault Systèmes BIOVIA, Discovery Studio, San Diego: Dassault Systèmes, 2016. San Diego. 2020, Retrieved from https://www.3dsbiovia.com/about/citations-references/.

48. Bui, H.T.B.; Ha, Q.T.K.; Oh, W.K.; Vo, D.D.; Chau, Y.N.T.; Tu, C.T.K.; Pham, E.C.; Tran, P.T.; Tran, L.T.; Mai, H.V. Microwave assisted synthesis and cytotoxic activity evaluations of new benzimidazole derivatives Tetrahedron Lett 2016, 57, 887-891, https://doi.org/10.1016/j.tetlet.2016.01.042. 